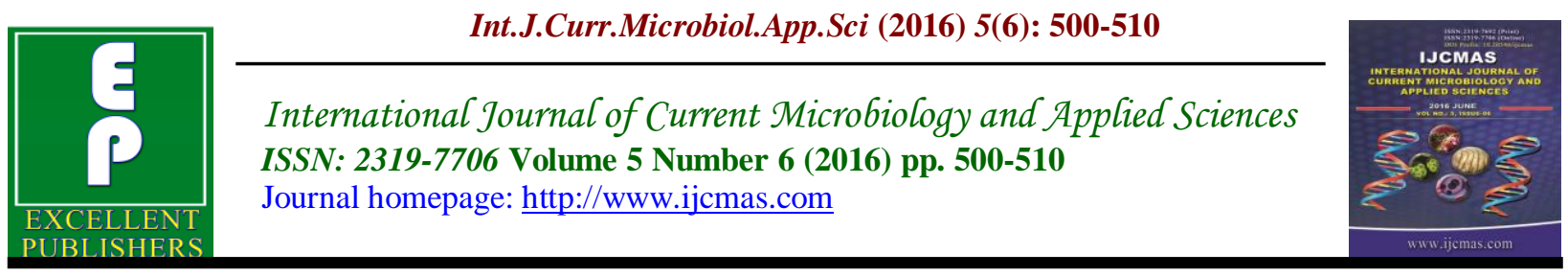

Original Research Article

http://dx.doi.org/10.20546/ijcmas.2016.506.056

\title{
Index of Bacterial Plaque in First Year Students of the Bachelor of Dental Surgeon at the Centro Universitario Metropolitano Hidalgo, Mexico
}

\author{
Pedro Macbani Olvera ${ }^{1}$, Graciela Aylin Ayala Molina², Uriel Alejandro Jerónimo Pascual ${ }^{2}$, \\ Blanca Leticia Reyes Barrera ${ }^{2}$, Patricia Vázquez Alvarado ${ }^{3}$ and \\ Jesús Carlos Ruvalcaba Ledezma ${ }^{4}$ \\ ${ }^{1}$ Profesor del Centro Universitario Metropolitano Hidalgo, Estudiante de la Maestría en Salud \\ Pública (UAEH) Universidad Autónoma del Estado de Hidalgo, Mexico \\ ${ }^{2}$ Estudiantes de la licenciatura en Cirujano Dentista en (CEUMH)Centro Universitario \\ Metropolitano Hidalgo, Mexico \\ ${ }^{3}$ Profesor Investigador de Tiempo Completo, Área Académica de Odontología, Depto. de Salud \\ Pública (UAEH). Universidad Autónoma del Estado de Hidalgo, Mexico \\ ${ }^{4}$ Profesor Investigador de Tiempo Completo, Área Académica de Medicina, Depto. de Salud \\ Pública (UAEH). Universidad Autónomadel Estado de Hidalgo, Mexico \\ *Corresponding author
}

\author{
A B S T R A C T
}

Keywords

Dental bacterial

plaque,

oral hygiene,

brushing

technique,

dental floss.

\begin{tabular}{l}
\hline Article Info \\
\hline Accepted: \\
20 May 2016 \\
Available Online: \\
10 June 2016
\end{tabular}

Determine the index of bacterial plaque in first year students of the degree of dental surgeon at the Centro Universitario Metropolitano Hidalgo. An observational descriptive study was conducted of a transversal nature in 16 students of both genders of between 17 and 24 years of age, the determination of the bacterial plaque was conducted by means of the method of pills revealing, of first entry to the degree of dental surgeon belonging to the University Center Metropolitan Hidalgo. Of the 16 students surveyed and analyzed that represent in the $100 \%$ presented bacterial plaque, the average age was 19.18 years, $5(31.25 \%)$ male, 11 $(68.75 \%)$ women, the prevalence of bacterial plaque was mild in $6.25 \%$ of them, moderate in $50 \%$ and severe in $43.75 \%$, it was detected that the poor oral hygiene and eating habits, apparently there is a relation of these with the prevalence of bacterial plaque. The prevalence of bacterial plaque in the students was $100 \%$, all students presented bacterial plaque, not with the same index apparently there is a relationship between other factors with the not visit to the dentist, poor dental hygiene, poor brushing technique and the inappropriate use of dental-floss.

\section{Introduction}

The present investigation seeks to measure the presence of bacterial plaque and its relationship with the poor oral hygiene of the young people of degree between 17 to 24 years, belonging to the University Center
Metropolitan Hidalgo (CEUMH) in the city of Pachuca Hidalgo, Mexico. This interest arose from which the bacterial plaque is a problem of public health. The bacterial plaque is a mass that is formed by the growth and colonization of microorganisms 
on the surface of the teeth, restorations and dental prostheses. As these microorganisms adhere and grow produce destructive substances for the dental tissues, in addition that the plate is a complex microbial community; as a consequence of the interactions between species, occurs a ecological niche that favors the growth and survival of species proteolytic anaerobic strict, as well as appropriate conditions for the development of periodontitis. This being the result of a series of processes that involve a variety of bacteria and components of the oral cavity. (Bascones Martínez et al., 2005; BasconesMartinez; Fernando Baños Francisco, 2013)

These processes includes the formation of the film acquired over the surface of organs, dental. The colonization of microorganisms comprises several phases involving the deposition, accession, congregation, growth and reproduction of the microorganisms adhere on the film acquired. (BasconesMartinez; CasalsPeidró Pacho Saavedra)

The presence of bacterial plaque is thus the inefficiency of the oral hygiene, not properly use dental floss, the mouthwash or even the non-use of these, as the poor brushing techniques, mean that the quantity of plate is even greater. (Víctor Lahoud et al., 2000)

This table was obtained from the epidemiological profile of the Oral Health in Mexico 2010, in this distribution is observed the presence of bacterial plaque and oral hygiene in children and adolescents; study conducted by the Epidemiological Surveillance System of pathologies buccal SIVEPAB 2009.

These components are evaluated in order to determine oral hygiene in the individual and his or her registration in the sentinel units, used the Simplified Oral Hygiene Index
(IHOS) developed by Greene and Vermillion, because it has proved to be a reliable instrument for epidemiological studies of great size. (Perfil Epidemiológico De La Salud, 2011)

This table was obtained in the epidemiological profile of Oral Health in Mexico 2010, this table shows the distribution of IHOS, on periodontal diseases and the age of the participants in the survey conducted by the Epidemiological Surveillance System of pathologies buccal SIVEPAB 2009.

\section{General Objective}

Determine the index of bacterial plaque in first year students of the degree of dental surgeon at the Centro Universitario Metropolitano Hidalgo.

\section{Specific Objectives}

1. Intervene in each one of the students with the implementation of the pads revealing.

2. Determine the frequency and distribution of risk factors associated with the presence of bacterial plaque in the sample of students.

3. Establish a plan of intervention that stimulate a response for the preventive care of oral health.

\section{Material and Methods}

\section{Participants}

The present study is descriptive, observational character cross. Where it counted with the participation of 16 students of both sexes, between 17 and 24 years, belonging to the University Center Metropolitan Hidalgo, during the first four months of the cycle september 2015 January 2016; which voluntarily participated and under an informed consent for filling the 
questionnaire was as results were obtained. The determination of the size of the sample was calculated using the formula that uses maximum variance of proportions, with a confidence level of $95 \%$ and a maximum allowable error of $5 \%$.

With these parameters are determined a minimum of 16 participants. It was considered as inclusion criteria to be enrolled in the University Center Metropolitan Hidalgo, as a criterion of exclusion not having assisted or not be present at the time of the survey.

\section{Instruments and Categories of Evaluation}

For the fulfillment of the proposed objectives, a questionnaire was designed. Which contained 2 categories, the first one was the identification of students, which complied with the rules of confidentiality and the second category on the oral hygiene and eating habits.

\section{Results and Discussion}

The present study surveyed 16 students $(100 \%)$. The average age was 19.18 , being 5 $(31.25 \%)$ male, 11 (68.75) of the female sex.

Within the questionnaire was asked how many times a day you brush your teeth the students, which courage as a result 6.25 per cent answered that brushing 1 time per day, 75 percent responded that 2 to 3 times brushing the teeth while 18.75 per cent responded that brushing 3 or more times a day. Taking into account that use brushing techniques different, the survey revealed that $37.5 \%$ use the technique Stillman1 and $62.5 \%$ use the technique circular or Fones2. (See Figure 4).

In an important way the surveys showed that 50 per cent of pupils replied that if they use dental floss and $50 \%$ do not use dental floss. On the other hand, the results obtained through the encuetan reveal that the $56.25 \%$ if using mouthwash $43.75 \%$ do not use mouthwash (See Figure 6).

Within the questionnaire they ask the students if they were subject to orthodontic treatment $25 \%$ of students responded that if they have orthodontic treatment, $75 \%$ of the students surveyed responded that they do not have orthodontic treatment.

In the questionnaire applied to the students, was of great relevance to ask when was the last time you visited the dentist in where $68.75 \%$ of the students answered that less than 6 months, $12.5 \%$ responded that more than 6 months and $18.75 \%$ that his last visit to the dentist had been over 1 year ago.

Table.1 Distribution of the Simplified Oral Hygiene Index (IHOS) in children and adolescents by group

\begin{tabular}{|l|r|r|r|r|r|}
\hline \multirow{2}{*}{ Agegroup } & \multicolumn{1}{|c|}{$\mathbf{N}$} & \multicolumn{5}{|c|}{ IHOS } \\
\cline { 3 - 6 } & & \multicolumn{1}{c|}{0} & 0.1 a 0.2 & 1.3 a 3 & 3.1 a 6 \\
\hline $\mathbf{2}$ a 5 & 3109 & 82.1 & 14.3 & 3.4 & 0.2 \\
\hline $\mathbf{6 ~ a ~ 9 ~}$ & 17807 & 58.2 & 33.8 & 7.7 & 0.3 \\
\hline $\mathbf{1 0}$ a 14 & 19560 & 48.7 & 38 & 12.3 & 1 \\
\hline $\mathbf{1 5}$ a 19 & 18963 & 41.3 & 38.2 & 18.4 & 2.1 \\
\hline Total & 59439 & 50.9 & 50.9 & 12.4 & 1.1 \\
\hline
\end{tabular}

Source: SSA, DGE, SIVEPAB $2009^{15}$ 
Table.2 Distribution of the Simplified Oral Hygiene Index by age group in users of health services Mexico SIVEPAB 2009.

\begin{tabular}{|c|c|c|c|c|c|}
\hline \multirow[t]{2}{*}{ Agegroup } & \multirow[t]{2}{*}{$\mathbf{N}$} & \multicolumn{4}{|c|}{ IHOS } \\
\hline & & 0 & 0.1 a 1.2 & 1.3 a 3.0 & 3.1 a 6 \\
\hline $20-24$ & 19749 & 36.3 & 37.1 & 23.6 & 3 \\
\hline 25-29 & 19548 & 32.6 & 37 & 26.5 & 3.8 \\
\hline $30-34$ & 18302 & 29.7 & 36.2 & 29 & 5.2 \\
\hline $35-39$ & 16708 & 27.4 & 35.8 & 30.9 & 5.9 \\
\hline $40-44$ & 13424 & 23.8 & 34.5 & 34.4 & 7.2 \\
\hline $45-49$ & 11456 & 21.5 & 33.4 & 35.9 & 9.2 \\
\hline $50-54$ & 88665 & 19.3 & 31.7 & 38.2 & 10.8 \\
\hline $55-59$ & 6885 & 19.3 & 30.8 & 38 & 12 \\
\hline $60-64$ & 4956 & 18.2 & 29.3 & 39.1 & 13.5 \\
\hline $65-69$ & 3525 & 18.5 & 27.5 & 39.1 & 14.8 \\
\hline 70-74 & 2219 & 17.7 & 25.4 & 40.6 & 16.4 \\
\hline $75-79$ & 1378 & 18.8 & 25.2 & 39.8 & 16.2 \\
\hline 80 y mas & 828 & 23.6 & 22.1 & 39.1 & 15.3 \\
\hline Total & 127643 & 27.1 & 34.5 & 31.4 & 7 \\
\hline
\end{tabular}

Source: SSA, DGE, SIVEPAB $2009^{15}$

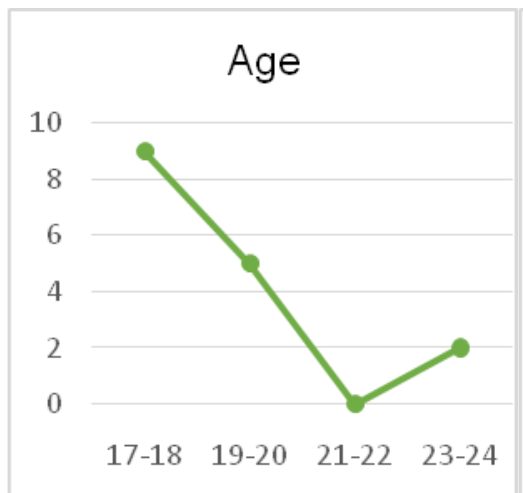

Figure 1 polygon of frequency of the ages of the students of first semester group to the degree of dental surgeon. University Center Metropolitan Hidalgo, November 2015.

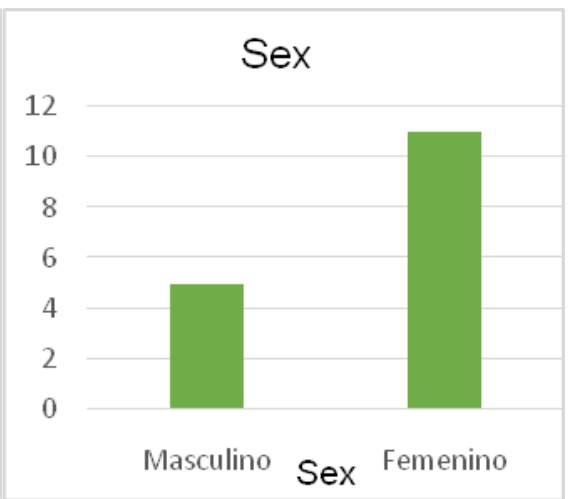

Figure 2 graphs of bars on the sex of the students of first semester group to the degree of dental surgeon. University Center Metropolitan Hidalgo, November 2015. 


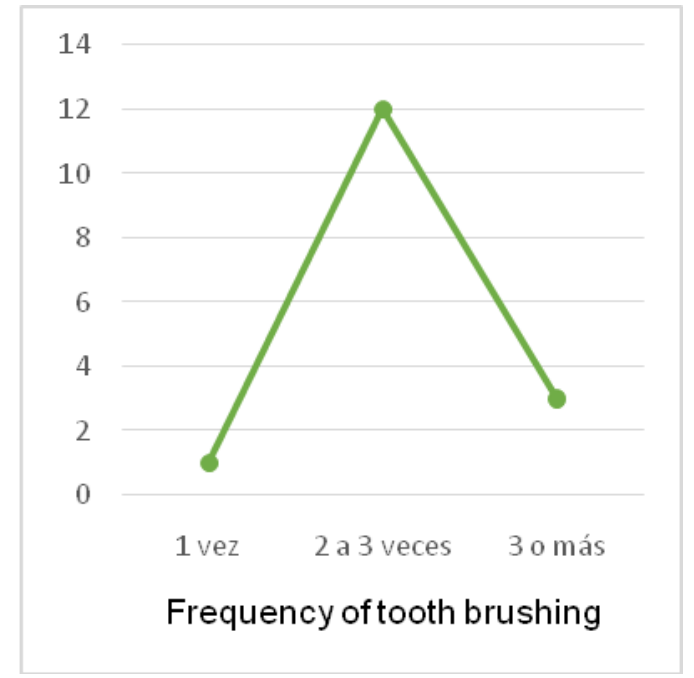

Figure 3 polygon of frequency of tooth brushing of pupils in first semester group to the degree of dental surgeon. University Center Metropolitan Hidalgo,

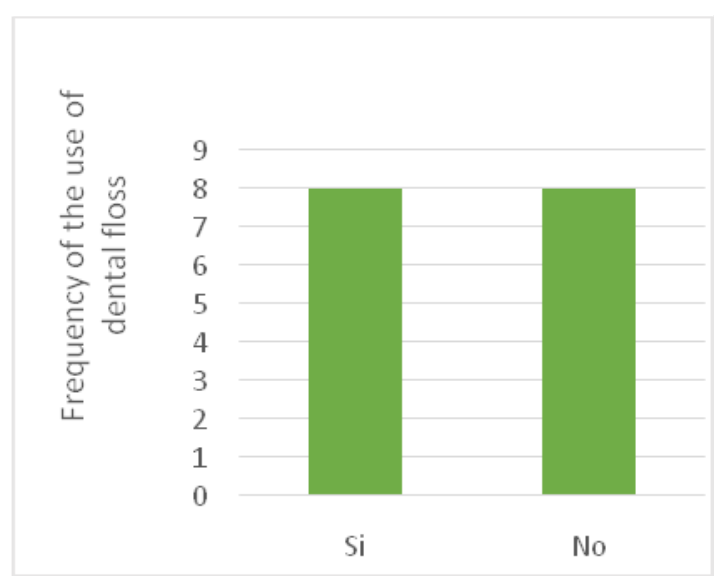

Figure 5 Graph flossing of pupils in first semester group to the degree of dental surgeon. University Center Metropolitan Hidalgo, November 2015.

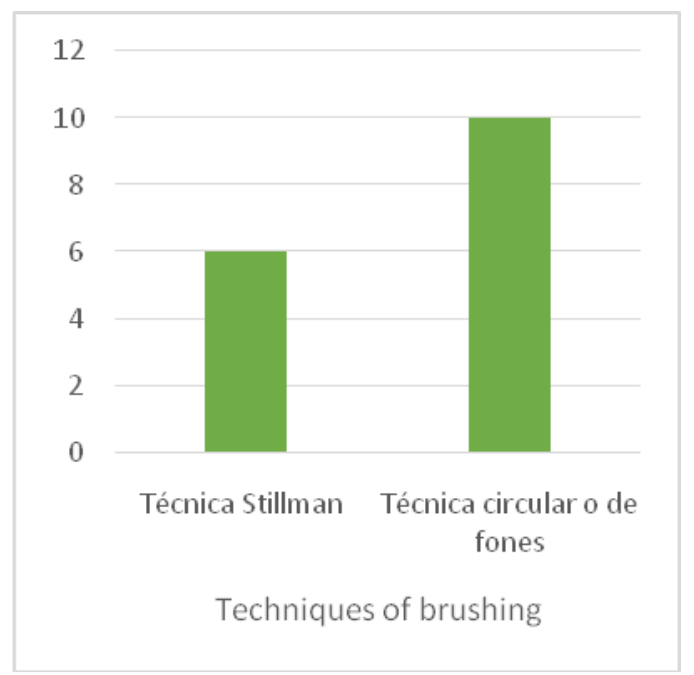

Figure 4 bar graph brushing technique of pupils in first semester group to the degree of dental surgeon. University Center Metropolitan Hidalgo, November 2015.

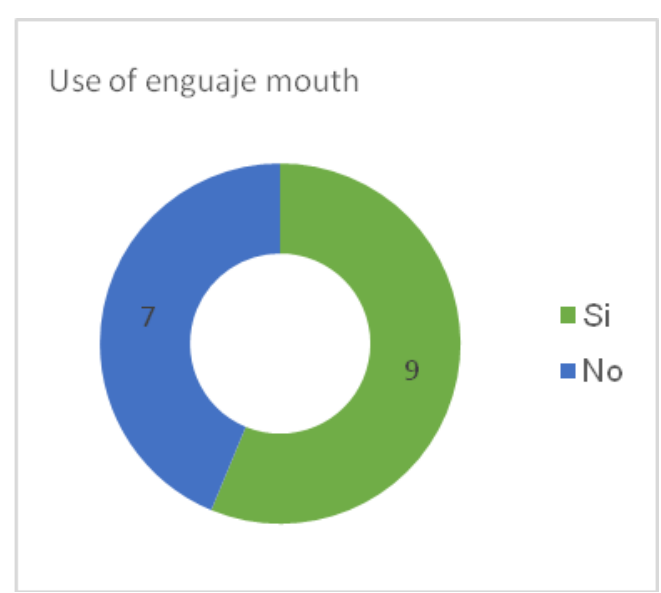

Figure 6 Chart use of mouthwash of pupils in first semester group to the degree of dental surgeon. University Center Metropolitan Hidalgo, November 2015. 


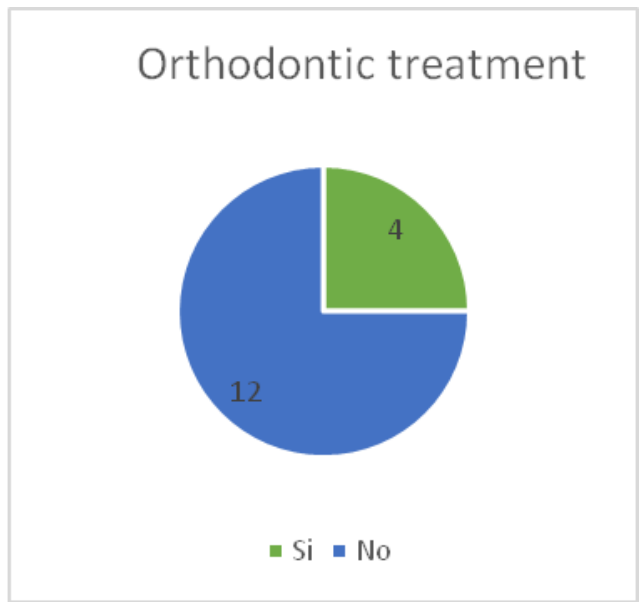

Figure 7 graphic orthodontic treatment of pupils in first semester group to the degree of dental surgeon. University Center Metropolitan Hidalgo, November 2015

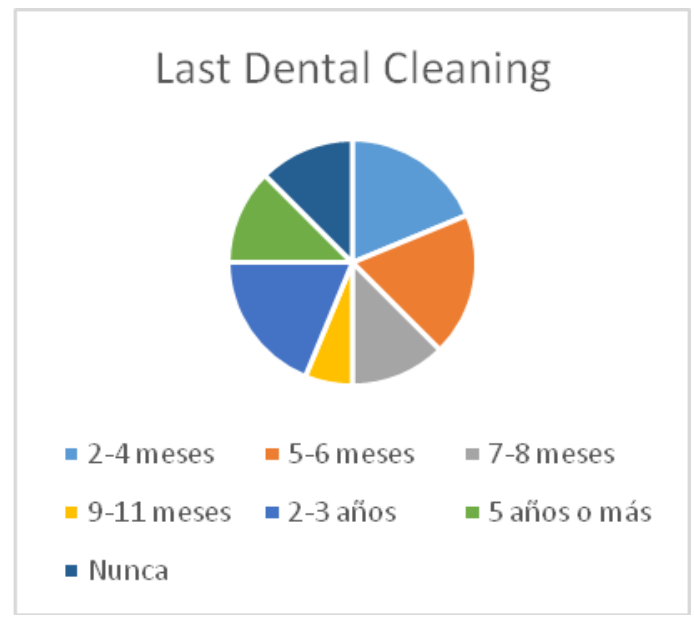

Figure 9 last dental cleaning of pupils in first semester group to the degree of dental surgeon.

University Center Metropolitan Hidalgo, November 2015.

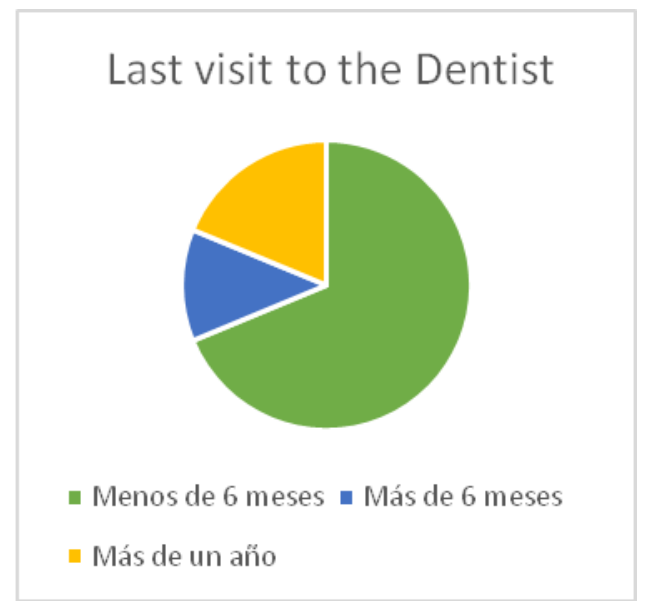

Figure 8 graphic last visit to the dentist of the pupils enrolled in the first semester group to the degree of dental surgeon. University Center Metropolitan

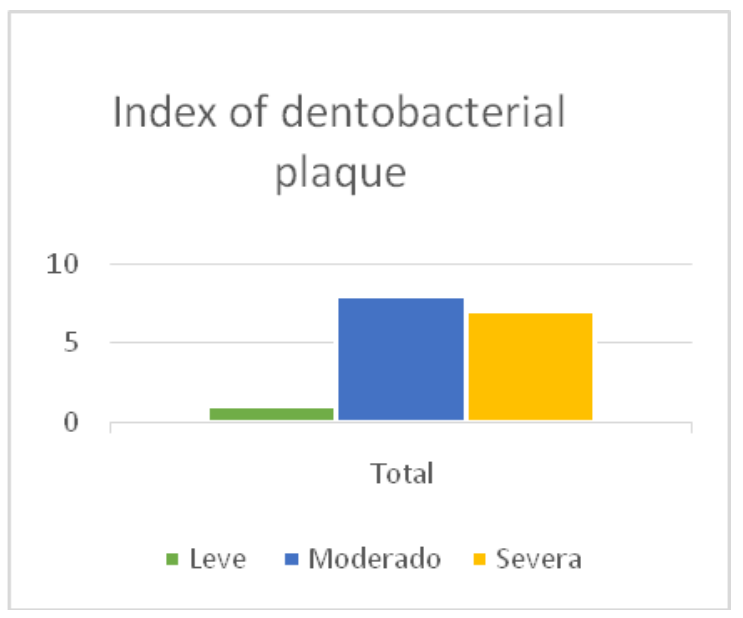

Figure 10 Graph Index of bacterial plaque of pupils in first semester group to the degree of dental surgeon. University Center Metropolitan Hidalgo, November 2015. 


\section{PHOTOGRAPHY}

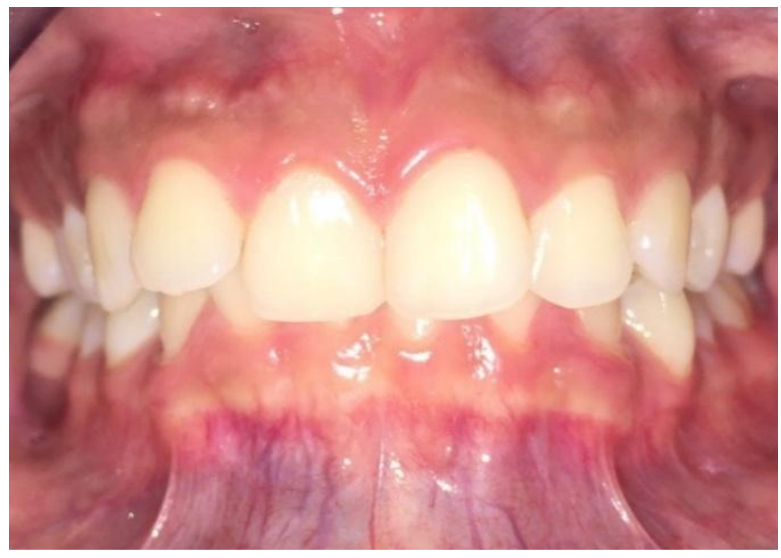

Patient No. 1 presents a level of bacterial plaque Moderate.

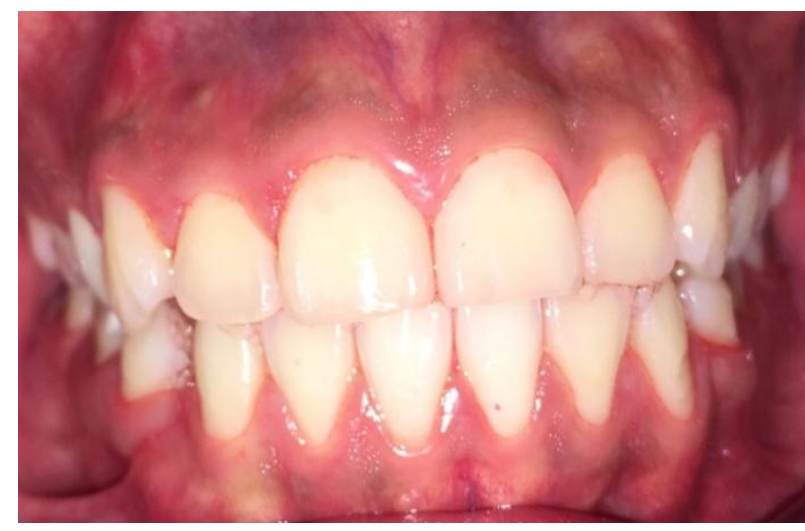

Patient No. 3 presents a level of bacterial plaque Moderate

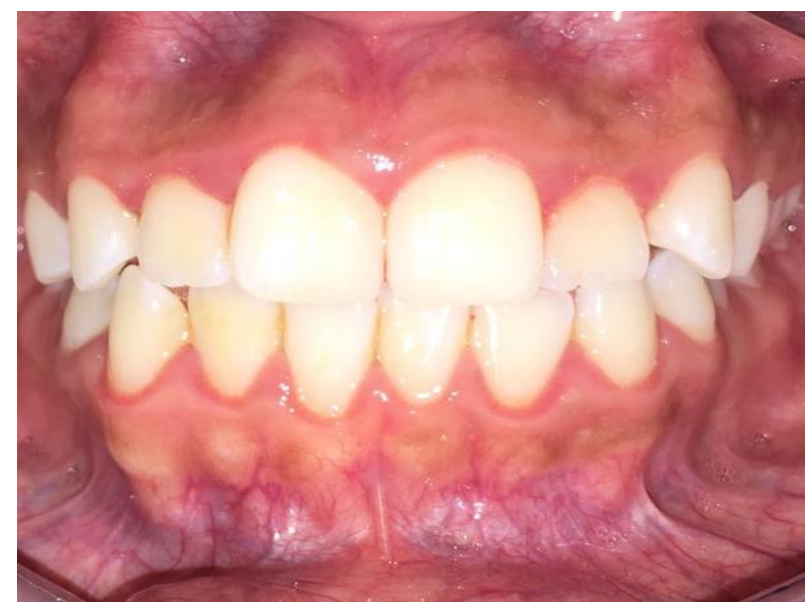

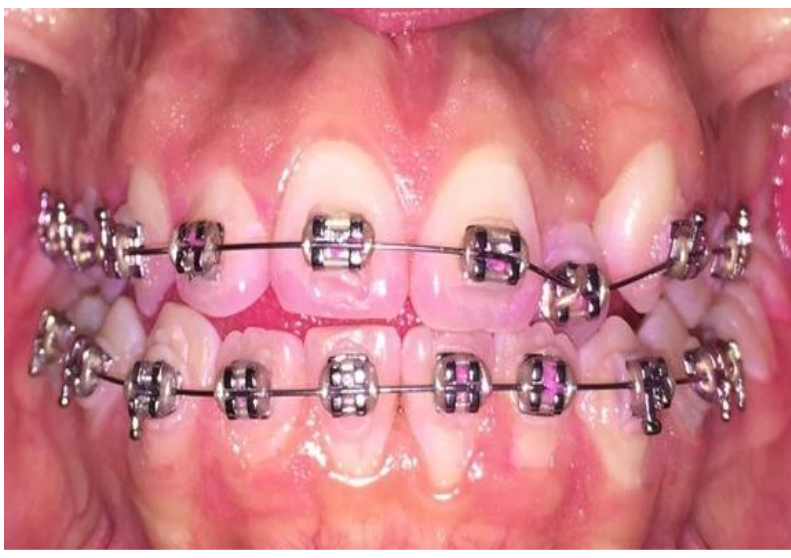

Patient No. 2 presents a level of bacterial plaque Severe.

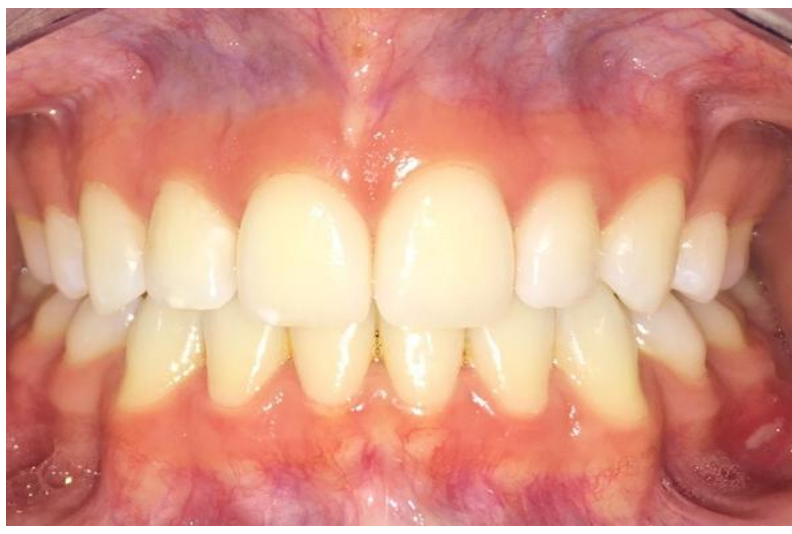

Patient No. 4 presents a level of bacterial plaque Slight

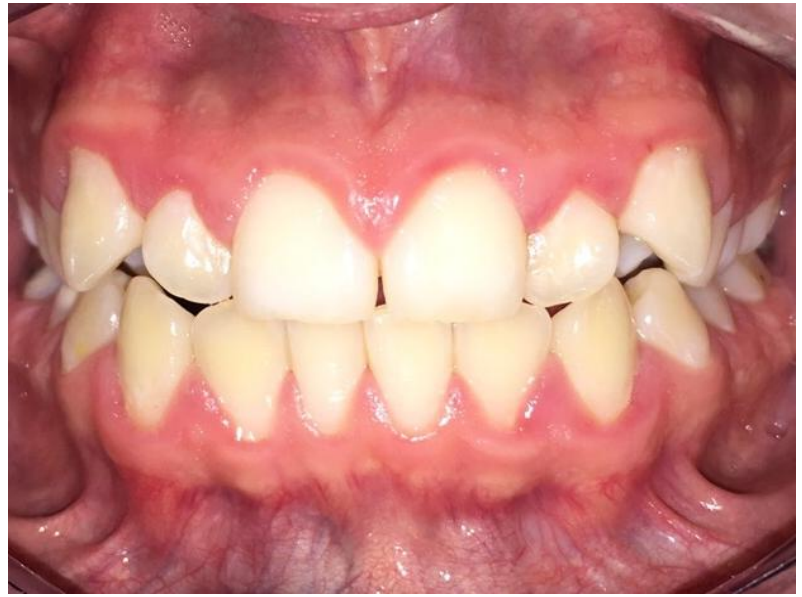



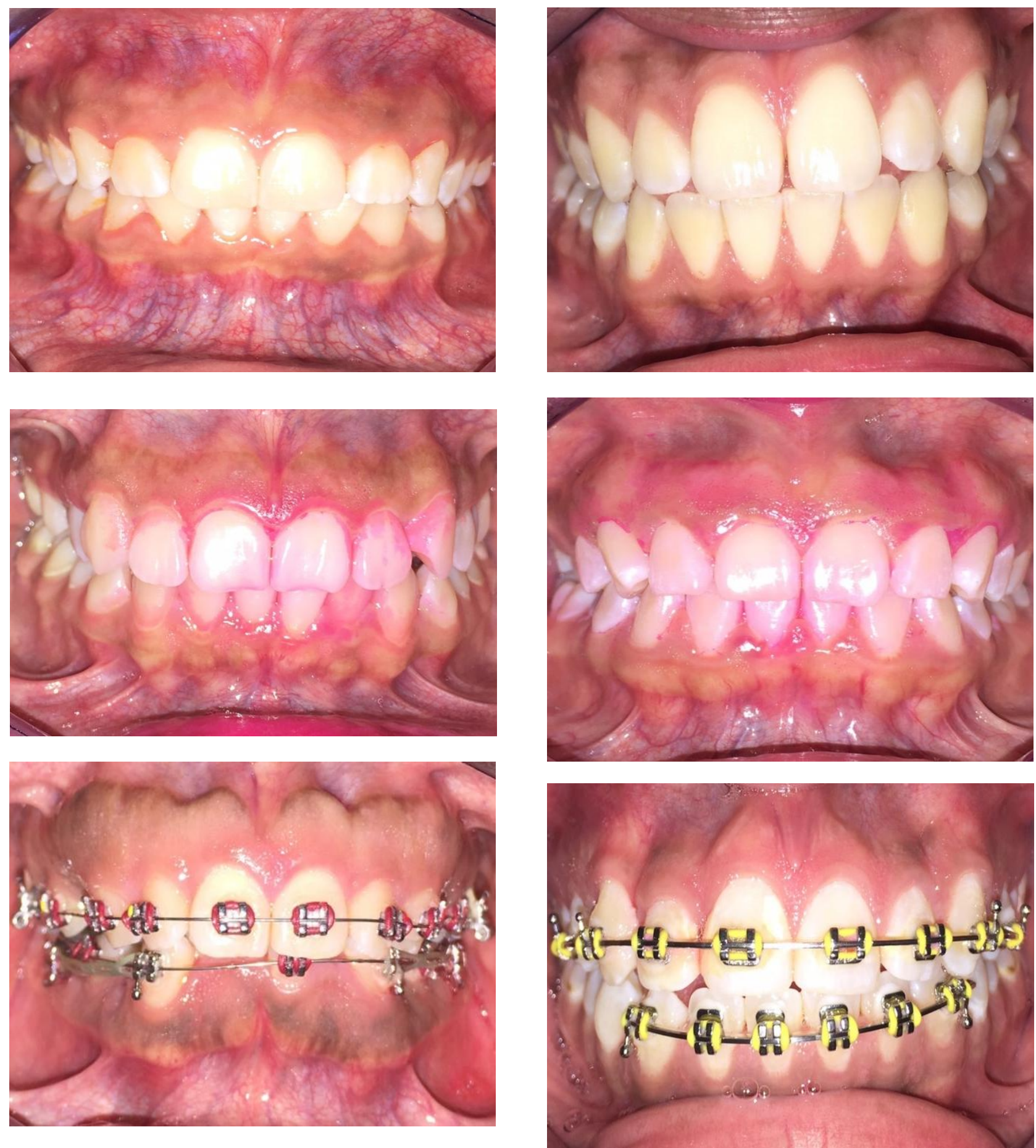


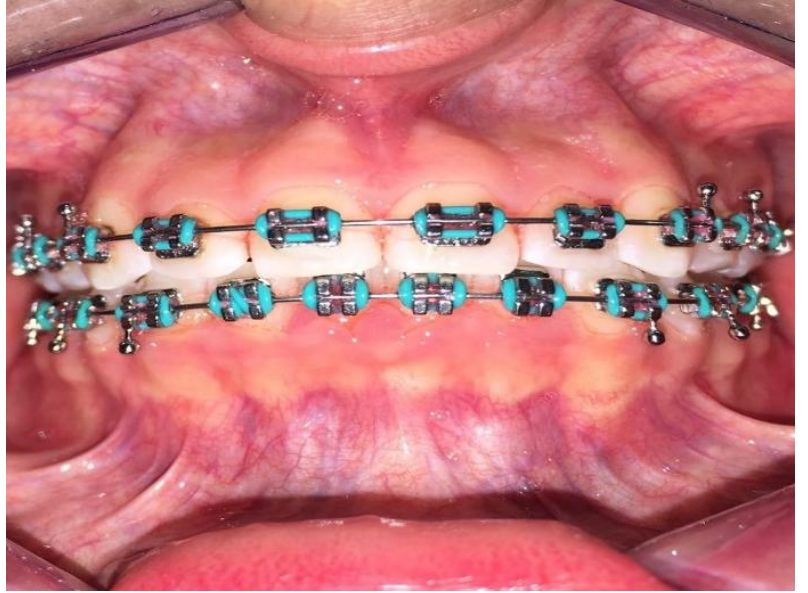

Patient No.13 presents a level of bacterial plaque Severe

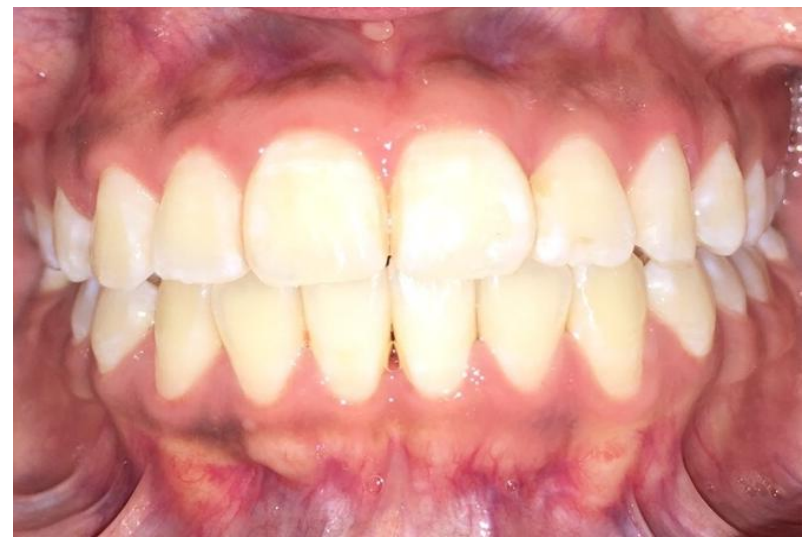

Patient No.15 presents a level of bacterial plaque Moderate

To perform the test with the pads revealing of plate, we were able to obtain the index of bacterial plaque of pupils, giving as a result 6.25 per cent of the pupils have a board level mild, $50 \%$ presented a moderate level of bacterial plaque and $43.75 \%$ present a severe level of bacterial plaque.

The index of bacterial plaque has a higher prevalence in the pupils with orthodontics, but above all with the students that do not

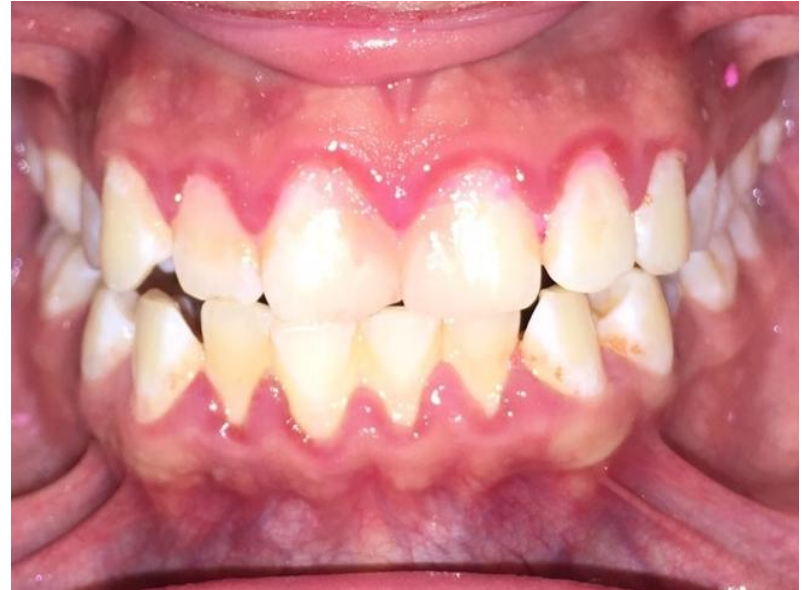

Patient No.14 presents a level of bacterial plaque Moderate

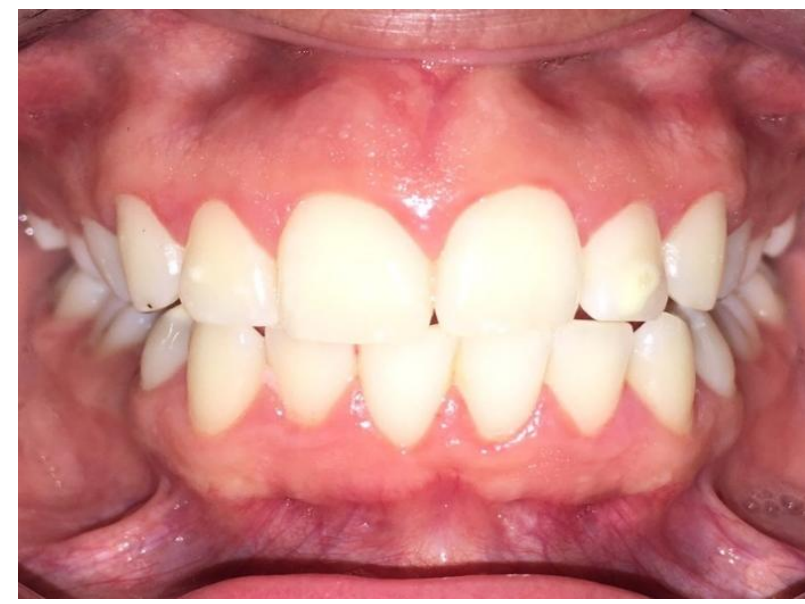

Patient No.16 presents a level of bacterial plaque Moderate

use mouthwash, dental floss and not brush your teeth at least 3 times a day, do not have a good brushing technique and not visiting the dentist frequently. As the level of bacterial plaque severe $(43.75 \%)$ is very close to the moderate $(50 \%)$, because there is only a difference of $6.75 \%$ throwing a high figure and worrying; since the bacterial plaque is a problem of public health.

It is of great importance for oral health, have 
a good hygiene is for this reason that you must know the correct techniques of brushing:

Technical Stillman amended: consists of placing the bristles to $45^{\circ}$ with respect to the root delos teeth on the zone of the gingiva, in a position similar to the method rotary, resting partially in the gum. The brush is located horizontally running a movement toward the area occlusal (i.e. the edge of the anterior teeth or the area of chewing later). It is a sweep from the gums to the tooth. This will clean the area interproximal (interdental) and is massaged the gingival tissue.

Technical Fones: the brush bristles are placed at $90^{\circ}$ with respect to the major axis of the tooth and the brush moves backwards as in wiping.

In conclusion, the prevalence of bacterial plaque in the students was $100 \%$, all students who were made the test showed bacterial plaque; although not with the same plate

index.

Students with more bacterial plaque are those who do not frequently use the dentist and have never made a dental cleaning.

Students with a plate index severe, have poor dental hygiene, not to use a good brushing technique and the misuse that give the flushing and not the not knowing properly use dental floss.

\section{References}

Bascones Martínez, A., Figuero Ruiz, E. 2005. Las enfermedades periodontales como infecciones bacterianas 2015, de Med Oral Patol Oral Cir Bucal Sitio web:http://scielo.isciii.es/scielo.php?sc
ript=sci_arttext\&pid=S1699-

65852005000300004

Bascones Martinez, A., Figuero Ruiz, E. Enfermedades periodontal Rev. Med Oral Patol Oral Cir Bucal Las enfermedades periodontales como infecciones bacterianas

Bascones Martinez, A., Figuero Ruiz, E. Rev. Med Bucal, Las enfermedades periodontales como infecciones bacterianas, Oral Patol.

Casals Peidró Elías, Hábitos de higiene oral en la población escolar y adulta española Rev. Biblid

Fernando Baños Francisco, Aranda Jacobo Refugió Placa bacteriana Rev. 2003. De la Asociación Dental Mexicana.

Giuseppe Anacleto Scarano, Arlando Correia, María Sueli, Eduardo Chimenos, Rosimar de Castro, Mónica PerdomoDetección de Helicobacter Pylori en placa dental y en mucosa gástrica de pacientes sometidos a endoscopia digestiva, Rev. Acta De Odontología Venezolana

González Catalina, Navarro Juan Carlos, López Paula Andrea Cambio. 2003. de indicadores de la placa dentobacteriana, gingivitis y caries en niños entre 2 y 5 años de edad a partir de una intervención educativa dirigida a madres de preescolar Medellin.

Pacho Saavedra José, A., Rodríguez Patterson María, C., Pico Ma. Pichardo, Higiene bucal: su repercusión en pacientes con tratamientos ortodóncicos Revista Cubana de Estomatología .

Pardi German, Cardozo de Pardi Elba Inés Placa dentobacterianaRelación entre la placa dental y la estomatitis subprotestica Rev. Acta De Odontología Venezolana

Perrone, M., Guilarte, C. 2004. Microorganismos de la placa dental relacionados con la etiología de la 
periodontitis10-11-2015, de scielo Sitio

web:http://www.scielo.org.ve/scielo.p

hp?pid=S0001-63652004000

300012\&script=sci_arttext

Poyato Ferrera, J.J., Segura Egea, V. Ríos

Santos, P. 2011. Bullón Fernández La

placa bacteriana, conceptos básicos para la higiene bucodental, Rev. Periodoncia, Vol. 11.

Rodríguez Calzadilla Amado, Delgado Méndez Luis. 1996 Diagnóstico de la salud bucal, Rev. Cubana Estomatol.,33.
Víctor Lahoud, S., Mendoza, Janett, Vacca, Gustavo. 2000. Prevalencia de placa bacteriana, caries dental y maloclusiones en 300 escolares de 6 a 14 años de edad. 10-11-2015, de Odontología Sanmarquina. Sitio web: http://sisbib.unmsm.edu.pe/bvrevistas/ odontologia/2000_n5/prevalencia.htm

Serrano GrangerJorge, Herrera David. La placa dental como biofilm ¿Cómo eliminarla?Rev. Biblid.

Perfil Epidemiológico De La SaludOral en México,Secretaria de Salud, 2010.

\section{How to cite this article:}

Pedro Macbani Olvera, Graciela Aylin Ayala Molina, Uriel Alejandro Jerónimo Pascual, Blanca Leticia Reyes Barrera, Patricia Vázquez Alvarado and Jesús Carlos Ruvalcaba Ledezma 2016. Index of Bacterial Plaque in First Year Students of the Bachelor of Dental Surgeon at the Centro Universitario Metropolitano Hidalgo, Mexico. Int.J.Curr.Microbiol.App.Sci. 5(6): 500-510. doi: http://dx.doi.org/10.20546/ijcmas.2016.506.056 